\title{
ПСИХОЛОГІЧНІ ОСНОВИ ФОРМУВАННЯ КОМУНІКАТИВНИХ УМІНЬ І НАВИЧОК УЧНІВ
}

Цоуфал Л. С. Психологічні основи формування комунікативних умінь і навичок учнів.

У статті розглянуто психологічні основи формування комунікативних умінь і навичок, обгрунтовано необхідність урахування психологічних властивостей та механізмів мовлення в процесі навчання мовленнєвої діяльності, охарактеризовано роль психічних процесів у розвитку мовленнєвих здібностей.

Ключові слова: мовленнєва діяльність, мовленнєва дія, мотив, пам'ять, мислення.

Цоуфал Л. С. Психологические основы формирования коммуникативных умений и навыков учащихся.

В статье рассматриваются психологические основы формирования коммуникативных умений и навыков, обосновывается необходимость учета психологических свойств и механизмов речи в процессе обучения речевой деятельности, характеризируется роль психических процессов в развитии речевых способностей учащихся.

Ключевые слова: речевая деятельность, речевое действие, мотив, память, мышление.

Coufal L. S. Psychological bases of formation of pupils' communicative skills.

The article deals with the psychological bases of formation of communicative skills, the necessity of the account of psychological properties and mechanisms of speech is proved during training speech activity, a role of mental processes in development of speech abilities of the pupils is characterized.

Key words: speech activity, speech action, motive, memory, thinking.

На сучасному етапі розвитку національної школи навчання рідної мови спрямоване на формування національно свідомої мовної особистості, яка володіє лінгвістичними знаннями та високим рівнем умінь і навичок в усіх видах мовленнєвої діяльності. Випускник школи повинен не тільки засвоїти основні розділи шкільного курсу української мови, а й навчитися використовувати мову як засіб спілкування і самовираження, ефективно сприймати інформацію в процесі аудіювання й читання, вільно висловлювати власні думки і почуття в усній та писемній формі.

Формування комунікативних умінь і навичок супроводжується цілим комплексом психічних процесів і дій, тому під час навчання мови необхідно враховувати психологічні властивості та механізми мовлення, особливості розвитку мовленнєвих здібностей учнів.

Мовленнєва діяльність визначається психологами як сукупність психофізіологічних дій людини, спрямованих на сприймання і розуміння мовлення або породження його в усній та писемній формах. Мовленнєва діяльність відображає психічну діяльність людини, розвиток і вираження іiі інтелекту й емоцій.

Мовленнєва діяльність характеризується всіма властивостями, що виділяються загальною теорією діяльності (цілеспрямованість, предметність, 
усвідомленість, перетворювальний характер), їх однаковою побудовою 3 необхідними компонентами у взаємозумовленості та різноманітних зв'язках, які забезпечують результат, до якого прагне людина.

Навчальна діяльність учнів зумовлюється цілями і мотивами. «Поняття діяльності, - зазначає О. Леонтьєв, - необхідно пов'язувати з поняттям мотиву. Діяльності без мотиву не буває; «немотивована» діяльність - це діяльність, не позбавлена мотиву, а діяльність з суб'єктивно й об'єктивно прихованим мотивом» [3, 153]. Досліджуючи проблему мотивів, Г. Костюк зазначав: «Характерною рисою всякої свідомої діяльності людини $є$ ii спрямованість на досягнення певних цілей. Цілі діяльності людини пов’язані з іiі мотивами. Мета діяльності - це те, на що вона спрямована i що повинно складати іiі прямий результат. Мотив - це те, що зумовлює прагнення людини до даної, а не якої-небудь іншої мети» [7, 428]. Важливо в процесі діяльності не лише визначити мотиви, але й забезпечити шляхи формування й розвитку мотивації. Перетворення мети в мотив діяльності позитивно впливає на процес формування комунікативних умінь і навичок, оскільки об'єктивно значуща мета стає особистісно значущою. Психологи зазначають, що діяльність складається з системи дій, а кожна дія - 3 операцій. Дією називають процес, що підпорядковується меті (цілям), операцією - спосіб реалізації дії. Мета мовленнєвої діяльності досягається за допомогою мовних засобів і специфічних мовленнєвих дій, у результаті яких виникає висловлювання, що повністю або частково відповідає меті.

Спосіб реалізації дії, або його операційний склад, досить рухомий i залежить від ситуації спілкування. Структура ж усіх дій однакова, вона складається з чотирьох послідовних і взаємозумовлених фаз: орієнтації, планування, реалізації і контролю.

Предметність і усвідомленість, взаємодіючи, створюють передумови для ефективної мовленнєвої діяльності. Якщо учень глибоко осмислить певний предметний зміст, то зможе дібрати відповідну мовну форму. Очевидно, що в цьому процесі певну роль відіграє внутрішнє мовлення, яке Л. Виготський називав головною ланкою переходу від думки до слова і від слова до думки. Школярам, що мають низький рівень розвитку внутрішнього мовлення, важко висловити свої думки вголос і сприйняти усне мовлення інших.

Перетворювальний характер мовленнєвої діяльності полягає в тому, що вона є важливим чинником у становленні учня як особистості.

Мовленнєва діяльність характеризується певною специфікою. Ця специфіка полягає в тому, що мовленнєва діяльність переважно виступає як невід’ємна частина іншого виду діяльності - трудової, навчальної, дослідницької, ігрової, забезпечуючи пізнання, спілкування, вплив, і ії мета визначається в екстралінгвістичному плані.

На думку А. Ксенофонтової, мовлення можна вважати самостійною діяльністю тоді, коли метою є «породження мовленнєвого висловлюван- 
ня», коли мовлення «самоцінне», коли без мовлення неможливе осмислення чого-небудь, коли мовлення співвідноситься з вираженням відношень, iз впливом на свідомість, із виробленням світогляду, норм поведінки, формуванням смаків тощо [2, 50].

Г. Шелехова зазначає, що «завдання розвитку мовлення повинно розглядатися як система двох взаємопов'язаних, але не зведених до одного завдань: збагачення мовленнєвої діяльності школярів і навчання вмінь, що забезпечують успішність цієї діяльності» $[8,4]$.

Удосконаленню мовленнєвої діяльності учнів сприятиме і цілеспрямоване навчання виконання окремих дій, що входять до структури мовленнєвого акту, тобто формування мовленнєвих умінь і навичок. У зв'язку з цим важливо відзначити, що набір таких умінь - єдиний протягом усього навчання в школі, тобто єдина система дій, із виконання яких складається конкретний акт мовленнєвої діяльності. У різних життєвих ситуаціях ці дії можуть здійснюватися більш-менш свідомо, при більшій чи меншій їх розгорнутості, проте склад їх загалом однаковий. Завдання і полягає в тому, щоб сформувати ці вміння, але на різних етапах навчання робити це на мовленнєвому матеріалі, різному з погляду стилю, типу, жанру, обсягу, змісту, характеру побудови тексту тощо.

Формування окремих мовленнєвих дій, спрямованих на розв'язання конкретного комунікативного завдання, передбачає навчання та усвідомлення умов такого завдання й адекватних їм мовних засобів $[8,4]$.

Відомо, що мовлення розгортається в багаторівневій динаміці механізму мовних одиниць - фонеми, морфеми, синтагми, речення. Розвиток, сприймання і породження мовлення здійснюється шляхом виділення елементів з цілого, а не шляхом утворення цілого з елементів. Слухач упізнає в тексті як багаторівневій динаміці одиниці мови i, завдяки утвореним у дитинстві навичкам, сприймає ціле речення. Замисел мовлення виникає 3 наміру, бажання, з упевненості в тому, що тема, на яку він буде говорити, потрібна, цікава слухачам. Мовець виконує дію - мовленнєвий вчинок, який мотивується його намірами. Мовленнєвий вчинок не можна зрозуміти без урахування ситуації спілкування [1, 47].

Залежно від спрямованості мовленнєвої дії на сприйняття або породження висловлювання, види мовленнєвої діяльності поділяються на рецептивні і продуктивні. До продуктивних належать говоріння і письмо, оскільки за їх допомогою людина здійснює повідомлення, а до рецептивних - слухання і читання, оскільки вони забезпечують прийом і подальшу переробку інформації.

Кожна мовленнєва дія містить етап підготовки висловлювання (усвідомлення мотивів, мети спілкування, прогнозування результатів), структурування висловлювання (відбір мовних одиниць, розташування їх у певному порядку), перехід до зовнішнього мовлення (звукове або графічне оформлення висловлювання). Про ефективність мовленнєвої дії свідчить реакція на висловлювання (зворотний зв’язок) [5, 268]. 
У реальному спілкуванні система мовленнєвих операцій не може бути заданою, адже відповідно до ситуації та її вимог людина по-різному будує висловлювання: в одних випадках звертається увага на зміст, грамотність, в інших - на швидкість, темп, експресивність мовлення. Це дає підстави вважати ситуацію спілкування не лише екстралінгвістичним чинником, а й психологічним.

Важливими психічними процесами під час навчання мови і формування комунікативних умінь і навичок $\epsilon$ відчуття й сприймання. Вони забезпечують відображення дійсності, усвідомлення ії як безпосередньо, так і опосередковано, тобто за допомогою мови. Відчуття й уявлення $є$ першим ступенем сприймання, за яким іде осмислення і розуміння.

Коли людина говорить або слухає, у неї мимовільно з'являються ті чи ті раніше складені наочні образи і схеми. Ці образи не передаються, тому ïх необхідно заміщати словами. У цьому й полягає процес розуміння. «Оскільки наочні образи суб' єктивні, не передаються і потребують перекладу, то такі переклади можуть бути різними в мовця і слухача» $[1,48]$. Унаслідок цього може виникнути між співрозмовниками нерозуміння.

Сприймання мовлення забезпечується тими самими механізмами, що й говоріння. Сприймання мовлення - це поетапний переклад сприйнятого на значеннєвий (предметно-зображувальний) код, ототожнення окремих слів, словосполучень, а також цілих фраз з нашим мовним досвідом.

Розуміння мовлення є завершальною стадією перекладу, коли відбувається співвіднесення змісту сприйнятого (усне висловлювання, прочитаний текст) із змістом нашої свідомості та різними чинниками діяльності. Коли учень буквально повторює прочитаний йому текст, не можна сказати, що він дійсно зрозумів прочитане. Зрозумівши загальний смисл, він завжди може його передати досить адекватно шляхом перекладу на свої слова.

Важливу роль у формуванні комунікативних умінь і навичок відіграє робота пам'яті - здатності людини утримувати в голові, у нейронних клітинах мозку, інформацію про світ і про себе. Пам'ять $є$ наріжним каменем психічного життя людини. Завдяки пам'яті вона може набувати потрібні для діяльності знання, уміння і навички. Залежно від матеріалу, який запам'ятовується, виокремлюють образну, словесно-логічну, емоційну та моторну пам'ять. За тривалістю утримання матеріалу, що запам'ятовується, пам'ять поділяють на короткочасну, довготривалу та оперативну.

Труднощі самостійного мовлення пояснюються неопрацьованістю оперативної мовленнєвої пам'яті. Формування цього механізму - одне 3 головних завдань розвитку мовлення в школі. В усному мовленні речення можуть бути коротшими, ніж у писемному, однак слід прагнути передусім правильності та різноманітності мовленнєвих конструкцій, а не збільшення кількості слів у реченнях.

М. Жинкін зауважує, що відбір слів із довготривалої пам'яті та конструювання речень в оперативній пам'яті підпорядковуються замислу ви- 
словлювання. Звичайно, якщо учень не знає предмета, про який слід щось сказати, мовлення не відбудеться. Письмові й усні твори на вільну тему нерідко бувають стандартними й нудними. Необхідно, щоб у мовця був замисел і смак до розповіді. Для цього треба збудити потребу грамотно, виразно про що-небудь розповісти. Гарного мовця захоплює передача задуму в простих словах, які із задоволенням і напруженою увагою слухають співрозмовники $[1,51]$.

Навчання мови як засобу спілкування здійснюється з урахуванням діалектичного зв'язку мислення й мовлення. Мислення - це узагальнене та опосередковане пізнання світу в процесі практичної і теоретичної діяльності людини, засіб творчості особистості.

Психологи вважають мовлення процесом матеріалізації думки, перетворення думки в слово. Оволодіння мовними засобами є необхідною умовою розвитку мислення та поступового ускладнення пізнавальної діяльності.

Мислення - ширше поняття, ніж мовлення, оскільки спирається не тільки на мову. Механізми мислення людей мають значний ступінь універсальності, мовлення ж має національну й соціальну диференціацію, стилістично забарвлене, тобто варіативне [5, 267].

Як складник пізнавальної функції психіки мислення спочатку існує у формі предметних дій і лише в результаті тривалого процесу, опосередкованого мовленням, набуває вигляду внутрішньої теоретичної діяльності. П. М'ясоїд зазначає: «Мислення - це внутрішня діяльність, яка опосередковується мовленням і здійснюється за допомогою певних дій та операцій» $[6,305]$.

Серед найважливіших операцій, що входять до складу мисленнєвої діiі, психологи вважають аналіз, синтез, порівняння, абстрагування й узагальнення. Їх необхідно враховувати й оптимально використовувати в процесі навчання мови для розвитку розумових здібностей дітей, осмисленого сприйняття мовного матеріалу.

Учені розрізняють внутрішне і зовнішнє мовлення. Внутрішне мовлення реалізується 3 великою швидкістю як мовне оформлення думки без iii висловлювання усно або на письмі. Зовнішне мовлення - це процес мовленнєвої діяльності: кодування (говоріння, письмо) і декодування (аудіювання, читання). Діяльність, спрямовану на створення зв'язних висловлювань, називають мисленнєво-мовленнєвою.

Важливо зауважити, що школярів необхідно навчати не якоїсь загальної мовленнєвої діяльності, а формувати власну мовленнєву діяльність. Для цього учні мають оволодіти засобами і способами реалізації кожного 3

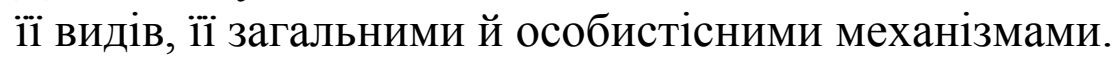

Досліджуючи психологію навчання мови як засобу спілкування, А. Маркова визначила загальні правила мовленнєвої діяльності, якими повинні керуватися учні, усвідомлено працюючи над своїм мовленням: 1) наявність у висловлюванні “смислу” як певної позиції мовця; індивідуальність мовлення починається з індивідуальності мислення; 2) важливість 
урахування при виборі мовних засобів умов і мети спілкування, процесу спілкування, тобто динаміку особливостей аудиторії. Для цього потрібні знання функціональних стилів мови, норм риторики, правил діалогу і монологу; 3) необхідність використання спеціальних мовних засобів для вираження свого суб'єктивного ставлення (модальні слова, різні експресивні засоби, підтекст) $[4,72]$.

Успішне формування комунікативних умінь і навичок на уроках української мови залежить від урахування вчителем особливостей мислення учнів, моделювання навчальних ситуацій, що спонукають до спостережень, бажання висловити свої думки і почуття. Постійна увага до пізнавальних можливостей, здібностей учнів, розуміння суті психічних процесів та механізмів мовлення сприяє результативності навчально-виховного процесу.

\section{Література}

1. Жинкин Н. И. Психологические основы развития мышления и речи / Н. И. Жинкин // Русский язык в школе. - 1985. - №1. - С. 47-54.

2. Ксенофонтова А. Н. Вопросы педагогической организации речевой деятельности в учебном процессе // Активизация учебно-познавательной деятельности учащихся: Межвуз. сборник научных трудов. - Л.: ЛГПИ, 1985. - С. 49-55.

3. Леонтьев А. Н. Деятельность. Сознание. Личность // Леонтьев А. Н. Избранные психологические произведения: В 2-х т. Т. ІІ. - М.: Педагогика, 1983. - С. 98-231.

4. Маркова А. К. Психология усвоения языка как средства общения / А. К. Маркова. - М.: Педагогика, 1974. - 240 с.

5. Методика навчання української мови в середніх освітніх закладах / [M. І. Пентилюк, С. О. Караман, О. В. Караман та ін.]; за ред. М. І. Пентилюк. - К.: Ленвіт, 2004. $-400 \mathrm{c}$.

6. М'ясоїд П. А. Загальна психологія: Навч. посіб. / Петро Андрійович М'ясоїд. - К.: Вища шк., 2000. - 479 с.

7. Психологія / за заг. ред. Г. С. Костюка. - К.: Радянська школа, 1968. - 568 с.

8. Шелехова Г. Формування комунікативних умінь на уроках української мови в 6 класі / Галина Шелехова // Українська мова і література в школі. - 2002. №8. - C. 4-10. 